Proceedings of the 24th International Symposium "The Environment and the Industry" (E-SIMI 2021), 24 September 2021, online event

\title{
A study regarding the parameters that influence the growth rate of Salix alba
}

\section{GABRIEL MURARIU ${ }^{1}$, RALUCA ENESCU ${ }^{2 *}$, DIANA VASILE ${ }^{2}$, LUCIAN DINCA $^{2}$, GEORGE DANUT MOCANU ${ }^{1}$, DAN MUNTEANU ${ }^{1}$}

\author{
${ }^{1}$ Dunarea de Jos University of Galati, 47 Domneasca Street, 80008, Galati, Romania \\ ${ }^{2}$ Marin Dracea National Institute of Research and Development in Forestry, 13 Closca Street, 400050, \\ Brasov, Romania \\ *Corresponding author: raluk.enescu@yahoo.com
}

$\begin{array}{lll}\text { Received: } & \text { Accepted: } & \text { Published: } \\ \text { 10.08.2021 } & 04.11 .2021 & 17.12 .2021\end{array}$

\begin{abstract}
The inventory and evaluation of growth rates for afforested surfaces is extremely important in estimating production levels and in determining the wood quantities that can be harvested. The present research was realized in southeast Romania, on a surface that contains $375 \mathrm{~h}$ of afforested fields. The monitored surfaces are situated in Hanu-Conachi Independenta Forest, at a relatively low altitude. The study took into account only the surfaces afforested with willow (Salix alba) and extended between 2010 and 2015. The afforested surfaces' consistency and age were evaluated based on direct observations and measurements. The used numerical analysis on different optimization methods was selected from amongst the most used series from the specialty literature. Our results have showed that evaluations of estimated production growth rates can vary significantly when different statistical analysis and numeric methods are use. By using numerical optimising models, computer simulations can offer precise estimations regarding growth rates, and consequently, for the efficiency of a given forest inventory. Common numerical interpolation methods or the usage of neuronal networks do not always lead to consistent results. Specific numeric methods are preferable for a better evaluation of growth rates and current inventory. In addition, investments in computer simulation methods and software should be encouraged in order to reach a permanent inventory, to improve the efficiency of exploitation operations and to sustain environment protection.
\end{abstract}

Keywords: numeric approach, statistical analysis, consistency, interpolation method, growth rate

\section{INTRODUCTION}

Willows are hygrophilous woody species that occupy humid forest habitats from meadows. There they form woods (willow shrubbery - Salix triandra; red osier - Salix purpurea; grey sallow - S. cinerea), white willow shrubbery and mixed shrubberies (poplar, willow, Adler). The species also participates in a lower percentage in meadow tugs or in other forest types [1-3]. Amongst them, adler, willow and ash forests are habitats protected at a European level - 91EO* Alluvial forests with Alnus glutinosa and Fraxinus excelsior (Salicion albae, Alno-Padion, Alnio incanae, UlmoFraxinetum), which include dominant white willow associations (Salicetum albae Issler 1924) and fragilis willow (Salicetum fragilis Passarge 1957) [4, 1].

White willow is commonly used in plantations with a rapid growth. In Europe, it is used in a conservation regime known as silviculture with short rotation [5]. White willow is very resistant to 
prolonged floods but is also very sensitive to the decrease of additional water supply (floods or phreatic) [6,7]. Under these conditions, intense dryings can appear.

Plantations with a rapid growth have an essential role in reducing $\mathrm{CO}_{2}$ emissions, by producing biomass for the substitution of fossils and by stocking $\mathrm{CO}_{2}$ in vegetation and soil $[8,9]$. In the new energetic context, both traditional willow cultures as well as those with a short circuit are reduced in discussions between specialists and practitioners [10-15]. The secondary usage of willow in rehabilitating polluted fields [16-19] or in modern medicine [20] are increasing the importance of this forest culture.

\section{MATERIAL AND METHODS}

\section{Research location}

The research took place in southeast Romania, on afforested fields situated in the public property of the east part of Galati County. For this study, Hanu Conachi Independenta Forest was selected, that belongs to the forest vegetation area of Covurlui Plateau. The research surfaces were grouped based on the dominant species, with the intention of having homogenous stand ages. The majority of surfaces are situated on a plain field, with a slope lower or equal with 5\%, even though some surfaces are situated in the hill area. Field configuration forces the majority of water streams to orient towards south, influencing also air currents. As such, precipitations are so reduced that Galati County is situated in what we name the country's dry area.

The study was realized on 356 (375ha of forest), while the research was concentrated on surfaces that have a $100 \%$ willow concentration. Measurements were realized each year, starting with 2010 and ending in 2015, towards the end of the vegetation season (September-October). The following parameters were taken into account: age, consistency, composition, average density, harvested volume.

\section{Methods}

Field registration method includes a standard set of measurements realised for each section of the studied area. In total, 35 surfaces with a $100 \%$ willow composition were selected. These surfaces have been monitored between 2010-2015, leading to a coherent database. The recordings were realized by trained personnel twice a year, for more reliable data.

Statistical analysis methods were used such as multifactorial methods for analysing variation (ANOVA) and multi-varied statistical methods such as PCA. The value of the trustworthy coefficient is considered equal with 0.05 (an acceptable value in most studies) [13].

The programs are recognised and used worldwide (StatSoft Statistica X and MATLAB). The statistical analysis methods were used in the first stages of the study. Different correlation coefficients between the measured dimensions were then analysed. The analysis were realized in order to identify key parameters. The MANOVA analysis (StatSoft Statistics) was used. Investigations methods were applied for comparison and confirmation procedures, by using PCA (StatSoft Statistics X and MATLAB) [21].

Numerical methods used in the present study includes a couple of numeric and interpolation analysis techniques [2, 12]. For interpolation in particular, we have used software programs that contain predefined interpolation procedures and methods: (a) square interpolation method; (b) the interpolation method that uses the smallest squares; (c) nonlinear interpolation, through neuronal networks.

\section{RESULTS AND DISCUSSIONS}

Next we will present the data set considered in this statistical analysis. Table 1 presents the values that briefly describe the properties of the considered data set. 
Table 1. Descriptive Statistics

\begin{tabular}{lcccccccc}
\hline & Mean & Median & Mode & Min. & Max. & $\begin{array}{c}\text { Standard } \\
\text { deviation }\end{array}$ & Skewness & Kurtosis \\
& & & & & & & & \\
\hline Current age (years) & 9.074 & 9.000 & 0.000 & 0.000 & 33.00 & 7.053 & 1.225 & 1.957 \\
Consistence (\%) & 0.698 & 0.800 & 0.900 & 0.000 & 0.900 & 0.271 & -1.690 & 1.922 \\
Volume (cubic m/ha) & 78.62 & 78.00 & 0.000 & 0.000 & 258.0 & 60.72 & 0.603 & -0.188 \\
Total Volume (c m) & 141.0 & 66.47 & 0.000 & 0.000 & 755.0 & 161.2 & 1.697 & 2.918 \\
Growth (c. m./year/ha) & 4.985 & 2.730 & 0.000 & 0.000 & 20.80 & 5.373 & 0.997 & -0.007 \\
Local growth (c. m./ha) & 10.74 & 5.070 & 0.000 & 0.000 & 58.74 & 13.96 & 1.816 & 3.100 \\
Extracted volume (c. & 7.710 & 0.000 & 0.000 & 0.000 & 397.0 & 49.23 & 7.185 & 51.46 \\
m./production unit) & 143.8 & 73.99 & 0.000 & 0.000 & 712.8 & 162.5 & 1.710 & 3.071 \\
Total net volume (c. m.) & 862.4 & 800.0 & 700.0 & 0.000 & 2000 & 541.6 & 0.359 & -0.324 \\
Density (no. specimens/ha) & & & & & & & &
\end{tabular}

The table above shows the values obtained for means, medians and standard deviation for all parameters included in the database: current age (in years), consistency, total volume recorded on each area considered, growth etc. However, there are some significant differences between the mean and median values. This fact which is quite interesting is encountered for some of the parameters studied such as consistency, total volume, growth. For the most part, the observed differences between the values of means and medians are slightly different due to the fact that some statistical distributions do not respect the conditions of normal distributions.

As it is known, when we have extreme scores, very high or very low compared to the data set, the median is a better indicator than the average. In the situation where the frequency of one category is much higher compared to the frequency of the other categories, the best indicator of the central trend is the mode. In our case, the distributions in all cases proved to be mostly modal ones that could be approximated with normal distributions with some exceptions (fig. 1).
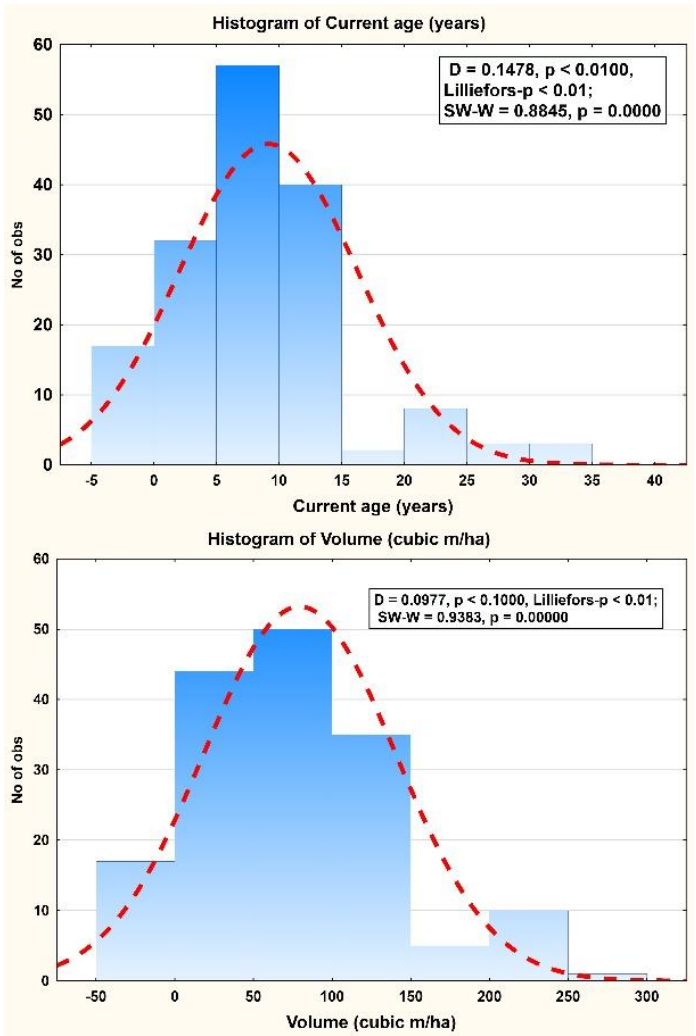
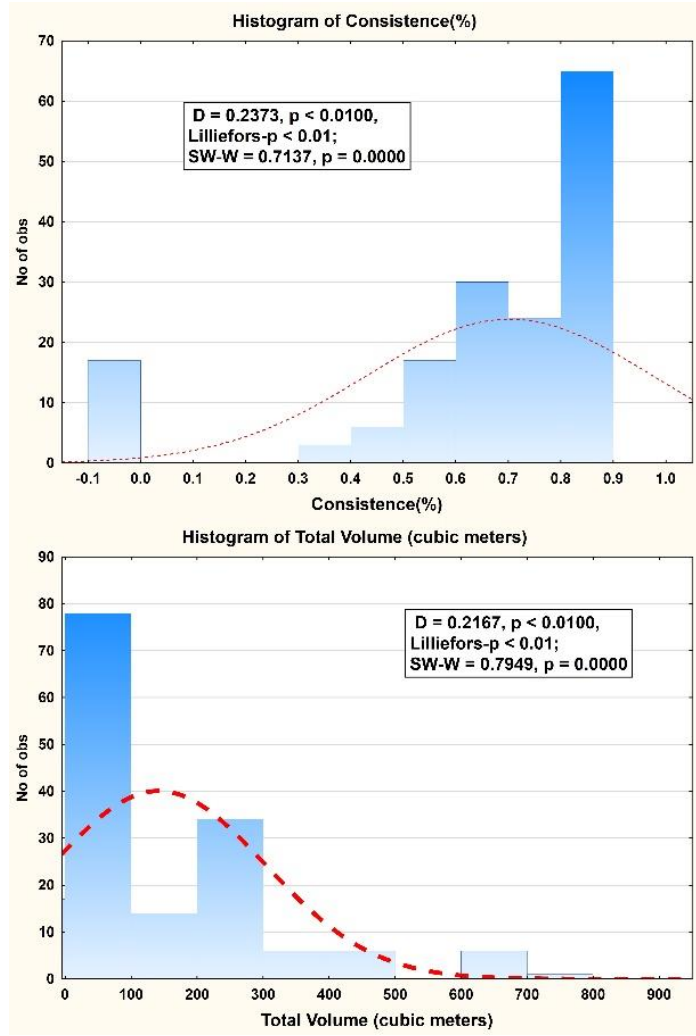

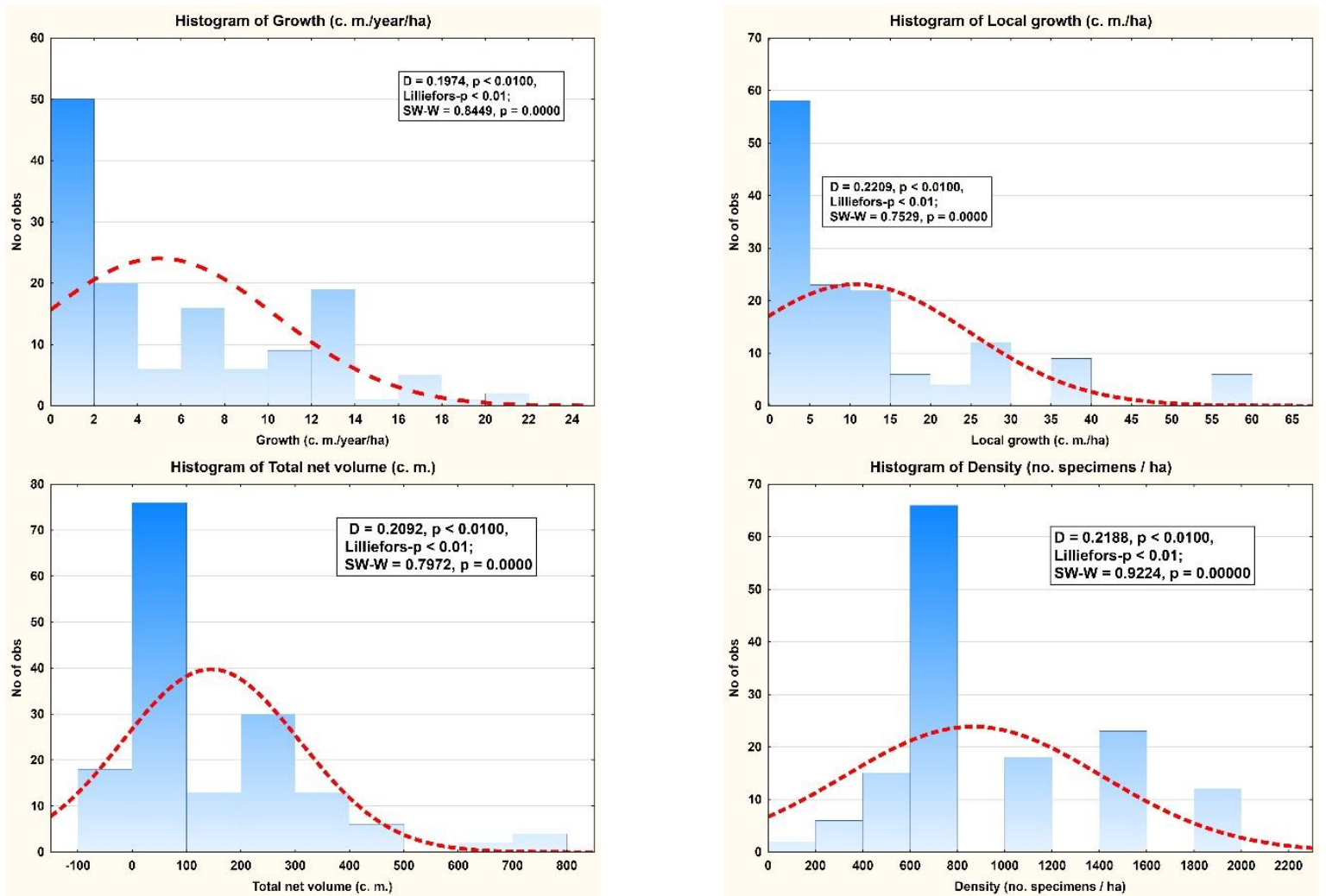

Fig.1. Histograms for the 8 studied parameters: (a) current age; (b) consistence; (c) volume; (d)total volume; (e) growth; (f) local growth; (g) total net volume; (h) density

In this sense, in figures $1 \mathrm{a}$ to $1 \mathrm{~h}$ are presented for the clarity of the exposure the histograms for the 8 studied parameters. Thus, it is observed that some statistical distributions do not respect the conditions of normal distributions. For this, the Kolmogorov-Smirnov test was applied. Thus, in each diagram is included the obtained result and thus we could demonstrate, through the obtained values and comparison with the critical values, the possibility of rejecting the hypothesis $\mathrm{H} 0$ ( $\alpha=$ $0.731<0.85$, Fig. $1 b$ (consistency); $\alpha=0.731<0.85$, Fig. $1 d$ (total volume); $\alpha=0.7972<0.85$, Fig. 1e (total net volume), etc.).

As it is known in the literature, a normal distribution is a single-mode distribution with only one category with maximum frequency, which determined the use of average values in statistical analyzes. The explanation of these differences consists in the fact that some of the parameters are calculated taking into account the sizes of the surfaces involved, which determines a change of distributions and a departure from normal.

The first step in analysing the data was to calculate correlation coefficients for the monitored measures. The correlation coefficients are presented in Table 2.

Table 2. Correlations (White willow (Salix alba) Marked correlations are significant at $p<0.05$,

$\mathrm{N}=162$ (Case wise deletion of missing data)

\begin{tabular}{lccccccccc}
\hline \multicolumn{1}{c}{ Variable } & $\begin{array}{c}\text { Current } \\
\text { age } \\
\text { (years) }\end{array}$ & $\begin{array}{c}\text { Consistence } \\
(\%)\end{array}$ & $\begin{array}{c}\text { Volume } \\
\left(\mathrm{m}^{3} / \mathrm{ha}\right)\end{array}$ & $\begin{array}{c}\text { Total } \\
\text { Volume } \\
\left(\mathrm{m}^{3}\right)\end{array}$ & $\begin{array}{c}\text { Growth } \\
\left(\mathrm{m}^{3} / \text { year/ha) }\right.\end{array}$ & $\begin{array}{c}\text { Local } \\
\text { growth } \\
\left(\mathrm{m}^{3} / \mathrm{ha}\right)\end{array}$ & $\begin{array}{c}\text { Extracted volume } \\
\left(\mathrm{m}^{3} / \text { production }\right. \\
\text { unit })\end{array}$ & $\begin{array}{c}\text { Total net } \\
\text { volume } \\
\left(\mathrm{m}^{3}\right)\end{array}$ & $\begin{array}{c}\text { Density } \\
(\mathrm{specimens} / \\
\text { ha) }\end{array}$ \\
\hline $\begin{array}{l}\text { Current age } \\
\text { (years) } \\
p \text { value }\end{array}$ & 1.000 & 0.229 & 0.557 & 0.321 & 0.180 & 0.199 & 0.318 & 0.234 & -0.366 \\
\hline $\begin{array}{l}\text { Consistence } \\
(\%)\end{array}$ & 0.0001 & 0.003 & 0.0001 & 0.0001 & 0.022 & 0.011 & 0.0001 & 0.003 & 0.0001 \\
\hline $\begin{array}{l}p \text { value } \\
\text { Volume }\end{array}$ & 0.229 & 1.000 & 0.544 & 0.410 & 0.312 & 0.347 & 0.060 & 0.413 & 0.592 \\
$p$ value & 0.003 & 0.000 & 0.0001 & 0.0001 & 0.0001 & 0.0001 & 0.445 & 0.0001 & 0.0001 \\
\hline $\begin{array}{l}\text { Density } \\
p \text { value }\end{array}$ & 0.557 & 0.544 & 1.000 & 0.697 & 0.193 & 0.340 & 0.354 & 0.612 & -0.137 \\
\hline
\end{tabular}


The first observation relates to the correlation coefficient between production volume on surface unit and current plantation age. The value of this coefficient specifies the strong relation between the surface and the recorded volumes. It must be noted that the production volume on surface unit is just the result of integrating the growth rate's value in time [22].

As a necessity, we have also examined and investigated the way in which the growth rate has varied based on the current age.

Table 3 shows the values of the MANOVA analysis in the case of independent parameters.

Table 3. Test of all effects for Growth ( $\mathrm{m}^{3} /$ year/ha)

\begin{tabular}{lccr}
\hline \multicolumn{1}{c}{ Effect } & $\begin{array}{c}\text { Degree of } \\
\text { Freedom }\end{array}$ & \multicolumn{1}{c}{$\begin{array}{c}\text { Wald } \\
\text { test }\end{array}$} & $P$ value \\
\hline Intercept & 1 & 0.230 & 0.630 \\
Current age (years) & 1 & 0.229 & 0.063 \\
Consistence $(\%)$ & 1 & 12.03 & 0.0005 \\
Volume $\left(\mathrm{m}^{3} / 1 \mathrm{ha}\right)$ & 1 & 4.369 & 0.036 \\
Extracted volume $\left(\mathrm{m}^{3} /\right.$ production unit) & 1 & 0.0003 & 0.986 \\
Total net volume $\left(\mathrm{m}^{3}\right)$ & 1 & 0.306 & 0.579 \\
Density (no. specimens/ha) & 1 & 2.038 & 0.153 \\
Local density (no. specimens/production unit) & 1 & 2.458 & 0.116 \\
\hline
\end{tabular}

It is observed that in relation to the values for current age (years) the dependence is insignificant $(p=0.063)$, and in relation to the values for consistency $(\%)(p=0.0001)$, volumes $\left(\mathrm{m}^{3} / \mathrm{ha}\right)(p=0.036)$ dependence is significant. The results of this analysis are presented in Figure 2. In contrast with other works from the specialty literature that follow only the interpolation's quality by mixing different models, the present paper has used a single form of mathematic models. It can be seen that the existing curve family is similar with very different interpolation parameters (Figure 2).

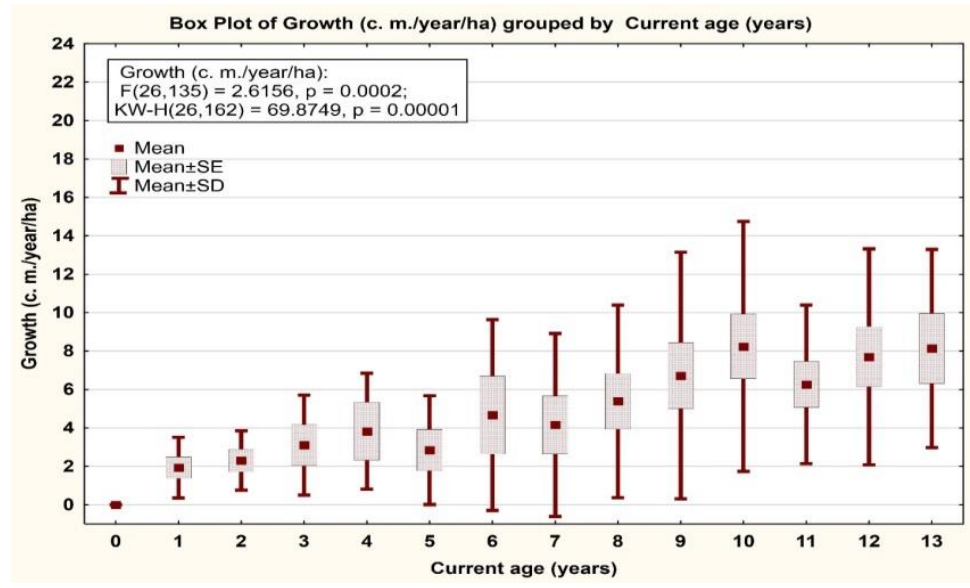

Fig. 2. Variation of growth rate based on age

Even though the research surfaces have the same soil type and climatic conditions, it is very interesting to see different growth rates with different coefficients. This observation has determined a univariate growth significance test, namely an ANOVA statistical analysis. The conclusion was very interesting: consistency (the equivalent area occupied by tree crown on surface unit) plays a very important role. The ANOVA analysis coefficients are presented in Table 2 and represent the study's first model.

As it can be seen in Table number 4, both parameters (actual age and surface consistency) have a clear influence on the growth rate $(p<0.001)$.

This type of subject is less studied in the literature, so the analysing the influence of consistency over the growth rate represents a valuable approach. 
Table 4. Univariate Tests of Growth Significance ( $\mathrm{m}^{3} / \mathrm{year} / \mathrm{ha}$ ) (Salix alba) Sigma-restricted parameterization Effective hypothesis decomposition

\begin{tabular}{lccccc}
\hline \multicolumn{1}{c}{ Effect } & SS & Degree of freedom & MS & F & \multicolumn{1}{c}{$\boldsymbol{p}$} \\
\hline Intercept & 1.132 & 1 & 1.131 & 0.043 & 0.835 \\
Current age (years) & 57.85 & 1 & 57.85 & 2.223 & 0.013 \\
Consistence (\%) & 359.8 & 1 & 359.8 & 13.82 & 0.0002 \\
Error & 4137.5 & 159 & 26.02 & & \\
\hline
\end{tabular}

Table 5 presents the testing characteristics for the complementary model to the one proposed in Table 4 namely the possibility of explaining growth rate by using other monitored parameters (current age and volume). The value of the $\mathrm{p}$ coefficient shows that this model is acceptable and usable $(p<0.0001)$.

Table 5. Univariate Tests of Growth Significance ( $\mathrm{m}^{3} /$ year/ha) (Salix alba). Sigma-restricted parameterization Effective hypothesis decomposition

\begin{tabular}{lccccc}
\hline \multicolumn{1}{c}{ Effect } & SS & Degree of freedom & MS & F & $\boldsymbol{p}$ \\
\hline Intercept & 9.934 & 1 & 9.933 & 0.376 & 0.540 \\
Current age (years) & 282.5 & 1 & 282.5 & 10.71 & 0.001 \\
Consistence (\%) & 3.738 & 1 & 3.737 & 0.141 & 0.707 \\
Error & 4191.6 & 159 & 26.36 & & \\
\hline
\end{tabular}

Both values for the quality evaluation model (meaning $\mathrm{R}^{2}$ and adjusted $\mathrm{R}^{2}$ ) as well as the values obtained for the p coefficient emphasize the quality of this model (Table 6).

Table 6. Test of SS Whole Model versus SS Residual

\begin{tabular}{|c|c|c|c|c|c|c|c|c|c|c|c|}
\hline $\begin{array}{c}\text { Dependent } \\
\text { variable }\end{array}$ & $\begin{array}{c}\text { Multiple } \\
\text { R }\end{array}$ & $\begin{array}{c}\text { Multiple } \\
\mathrm{R}^{2}\end{array}$ & $\begin{array}{c}\text { Adjusted } \\
\mathrm{R}^{2}\end{array}$ & $\begin{array}{c}\text { SS } \\
\text { Model }\end{array}$ & $\begin{array}{c}\mathrm{df} \\
\text { Model } \\
\end{array}$ & $\begin{array}{c}\text { MS } \\
\text { Model }\end{array}$ & $\begin{array}{c}\text { SS } \\
\text { Residual }\end{array}$ & $\begin{array}{c}\text { df } \\
\text { Residual }\end{array}$ & $\begin{array}{c}\text { MS } \\
\text { Residual }\end{array}$ & $\mathrm{F}$ & $p$ \\
\hline $\begin{array}{l}\text { Growth } \\
\left(\mathrm{m}^{3} / \text { year/ha) }\right.\end{array}$ & 0.324 & 0.105 & 0.070 & 490.3 & 6 & 81.72 & 4158.2 & 155 & 26.82 & 3.046 & 0.007 \\
\hline
\end{tabular}

However, ANOVA method is considered a special case of linear regression, which on its turn, is a special case for general linear representation. All these procedures consider that observations are the sum of a model (fit) and of a residue (error) that must be minimalized. All the following models will be improvements of this representation.

The square approach model represents an improvement of the previous linear model. The expression for this model takes the following shape:

$$
f(x, y)=a+b x+c y+d x^{2}+e x y+g y^{2}
$$

where $f=f(x, y)$ is the growth rate as a function, $x$ represents consistency value and $y$ is the current age.

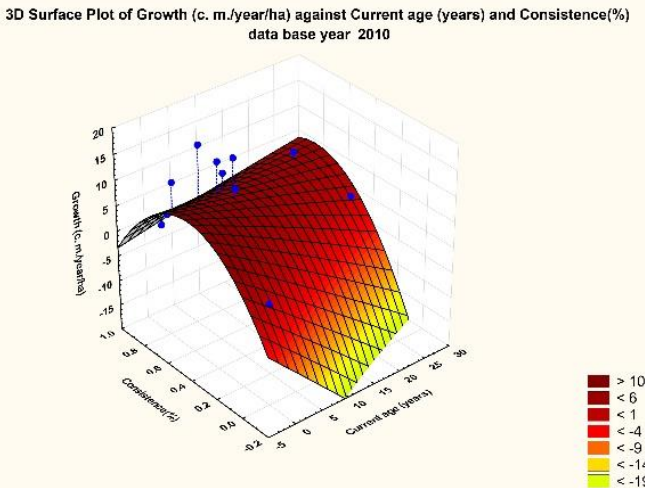

(a) Models with growth rates using square

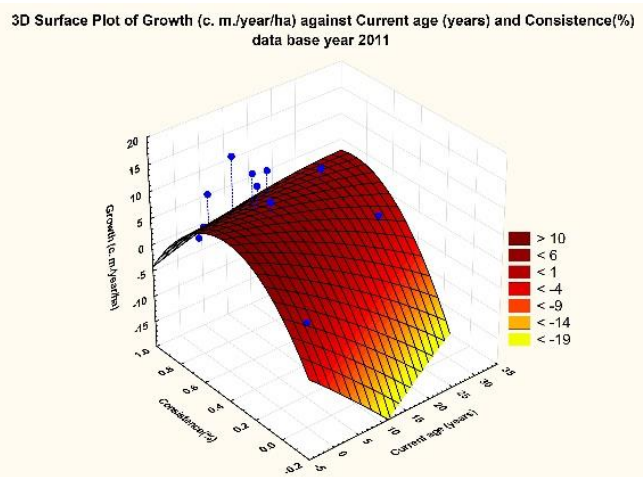

(b) Models with growth rates using square 
interpolation expressions, year 2010

30 Surface Plot of Growth (c. m./yeariha) against Current age (years) and Consistence(\%)
data base year 2012

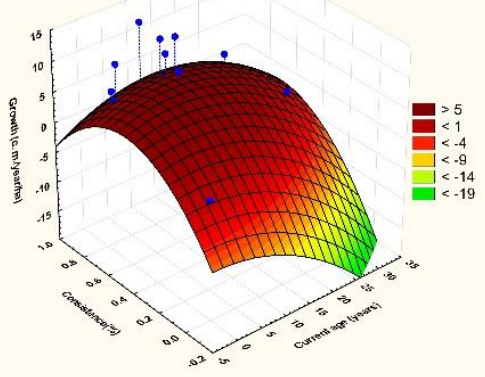

(c) Models with growth rates using square interpolation expressions, year 2012

30 Surface Plot of Growth (c. m./year/ha) against Current age (years) and Consistence(\%)
data base year 2014

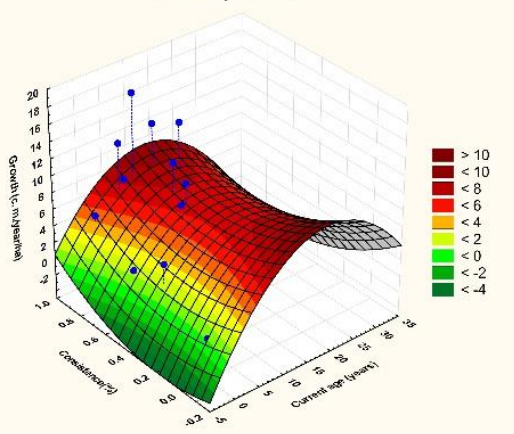

(e) Models with growth rates using square interpolation expressions, year 2014 interpolation expressions, year 2011

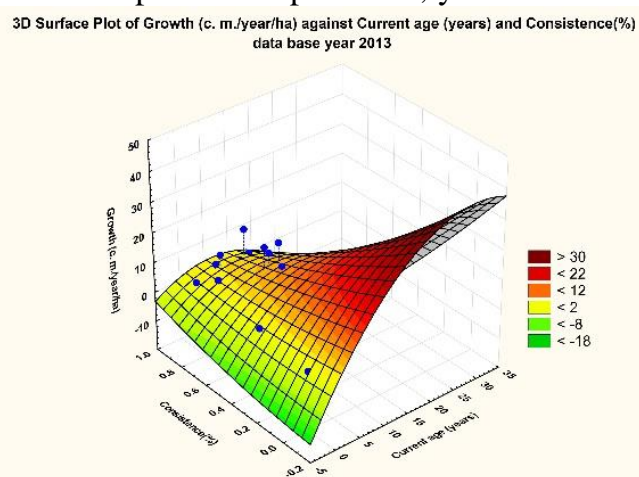

(d) Models with growth rates using square interpolation expressions, year 2013

30 Surface Plot of Growth (c. m.'year/ha) against Current age (years) and Consistence (\%)
data base year 2015

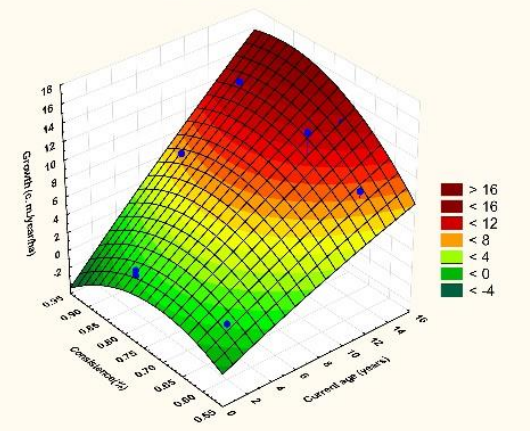

(f) Models with growth rates using square interpolation expressions, year 2015

Fig. 3. Models with growth rates using square interpolation expressions

Figure 3 presents the models obtained for each year of study. In this representation, the vertical axis represents the increase of the growth rate, while the horizontal axis are consistency and current age. The representations from Figure 3 have represented models found for the database recorded for each year. Even though these square model are more performing than the ANOVA method (where SS dimensions are lower), these representations continue to have some deficiencies. One such deficiency originates from the significant change of the obtained results from one year to another, while another deficiency relates to an important change in the shape of the represented area, which corresponds to the significant change in production evolution (figures $3 \mathrm{a} \div 3 \mathrm{f}$ ). The overall SS Model is about 470.55 , which is a better result than the previous one.

The model that uses the method of the smallest squares represents an additional improvement of the previous model. This method is based on the previous PCA analysis that allows the construction of response surfaces (Figure 4).

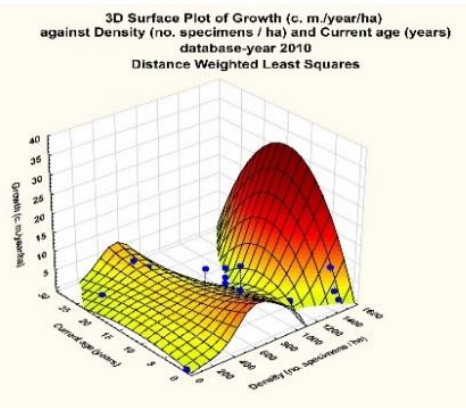

(a) Models for evaluating growth rates by using the DWLS interpolation method - year 2010

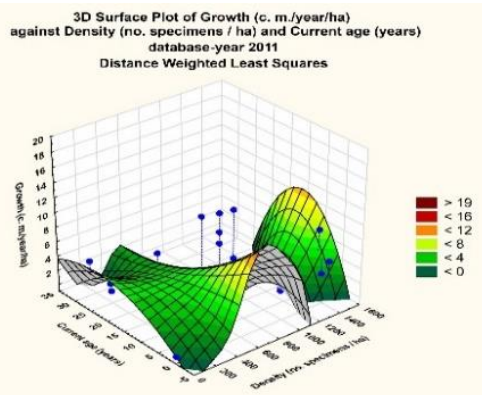

(b) Models for evaluating growth rates by using the DWLS interpolation method - year 2011 


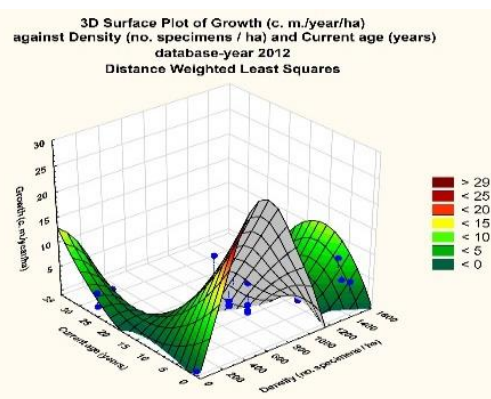

(c) Models for evaluating growth rates by using the DWLS interpolation method, 2012

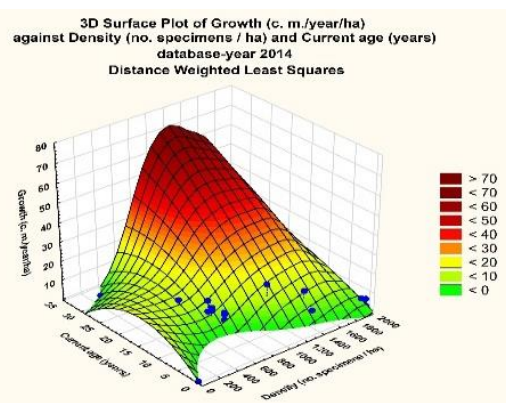

(e) Models for evaluating growth rates by using the DWLS interpolation method, 2014

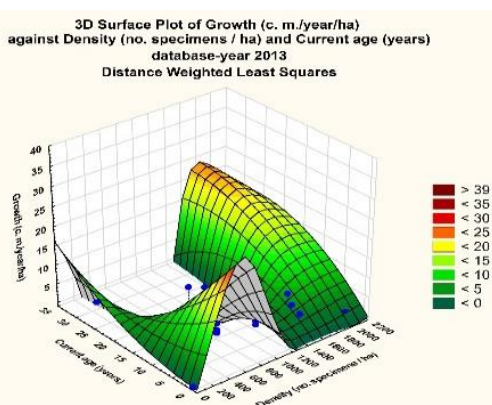

(d) Models for evaluating growth rates by using the DWLS interpolation method, 2013

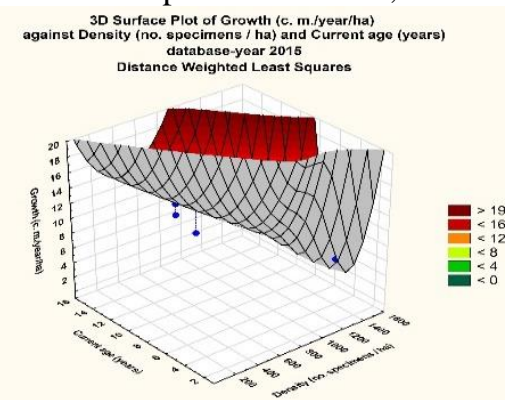

(f) Models for evaluating growth rates by using the DWLS interpolation method, 2015

Fig. 4. Models for evaluating growth rates by using the interpolation method with the help of the smallest squares

Even though models based on the smallest squares are more performing than the previous square representations, these approaches still have some deficiencies.

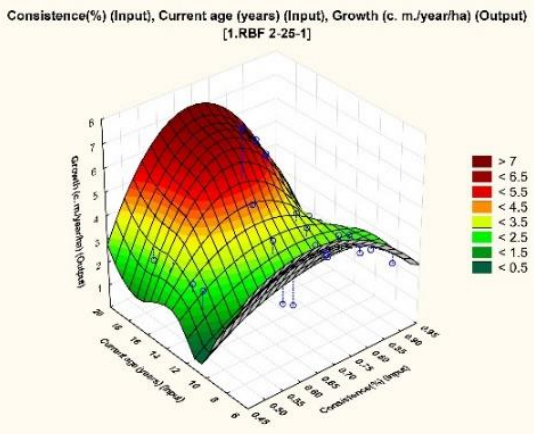

(a) Model for evaluating growth rates by using the interpolation method from neuronal networks, 2010

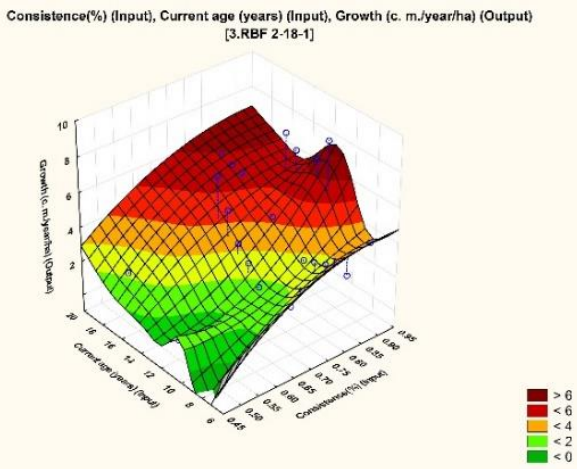

(c) Model for evaluating growth rates by using the interpolation method from neuronal networks, 2012

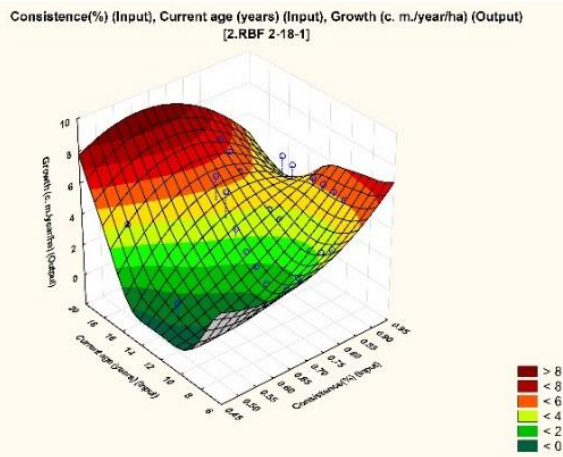

(b) Model for evaluating growth rates by using the interpolation method from neuronal networks, 2011

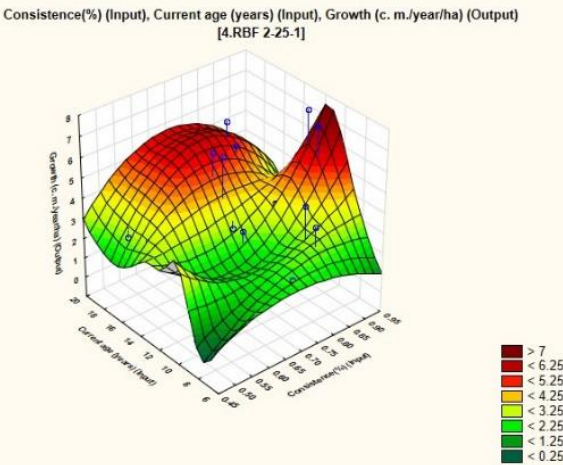

(d) Model for evaluating growth rates by using the interpolation method from neuronal networks, 2013 


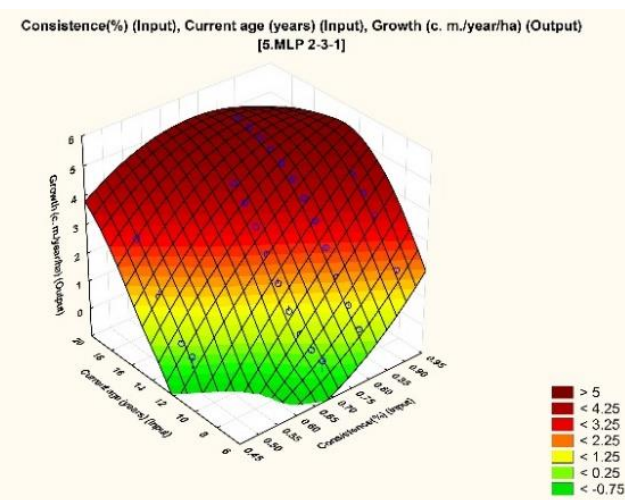

(e) Model for evaluating growth rates by using the interpolation method from neuronal networks, 2014

Fig. 5. Model for evaluating growth rates by using the interpolation method from neuronal networks

As expected, the performance of the model is increased (SS Model <467.50) but there are oscillations and sharp variations of the graph - Runge effect.

The next type of studied models is based on using neuronal networks (Figure 5). In this case, based on the values of the two monitored parameters (consistency and current age - considered as entry parameters) leads to an evaluation of growth rate (considered as exit value). These models have a better efficiency than the previous models. In this approach, we have used the results obtained previously in the interpolation method [21]. This model also involved taking into account 20 different RBF and MLP structures, while keeping the most performing model.

Table 7 presents the first 6 best models that obtained the best scores in the process of training, testing and validation, respectively. For the beauty and completeness of the results we present for each this check, the first 2 best performing models in each test category.

Table 7. Summary of active networks

\begin{tabular}{ccccccccc}
\hline \multirow{2}{*}{ No. } & Network name & \multicolumn{2}{c}{ Training } \\
performance & $\begin{array}{c}\text { Test } \\
\text { performance }\end{array}$ & $\begin{array}{c}\text { Validation } \\
\text { performance }\end{array}$ & $\begin{array}{c}\text { Training } \\
\text { error }\end{array}$ & Test error & $\begin{array}{c}\text { Validation } \\
\text { error }\end{array}$ & $\begin{array}{c}\text { Training } \\
\text { algorithm }\end{array}$ \\
\hline 1 & MLP 4-7-1 & 0.951225 & 0.959738 & 0.938544 & 182.5016 & 132.0989 & 198.9781 & BFGS 66 \\
2 & MLP 4-3-1 & 0.947725 & 0.947204 & $\mathbf{0 . 9 5 2 6 5 5}$ & 197.2436 & 170.1203 & 156.5313 & BFGS 159 \\
3 & MLP 4-9-1 & $\mathbf{0 . 9 7 5 2 2 4}$ & $\mathbf{0 . 9 7 5 5 4 5}$ & 0.951746 & $\mathbf{9 3 . 8 4 6 0}$ & 90.8853 & $\mathbf{1 5 5 . 6 8 4 9}$ & BFGS 167 \\
4 & MLP 4-10-1 & 0.960956 & 0.963928 & 0.942549 & 146.7885 & 118.0971 & 185.5028 & BFGS 95 \\
5 & MLP 4-7-1 & $\mathbf{0 . 9 6 8 8 4 8}$ & $\mathbf{0 . 9 7 7 1 3 2}$ & $\mathbf{0 . 9 5 2 5 7 0}$ & 117.6466 & $\mathbf{7 7 . 1 6 0 7}$ & 162.7201 & BFGS 113 \\
6 & MLP 4-4-1 & 0.951179 & 0.958721 & 0.946356 & 182.6932 & 132.7632 & 171.5825 & BFGS 109 \\
\hline
\end{tabular}

This fact has lead us to the idea of building a specific model, in order to improve the results obtained up to this point. In this regard, we have used a technique from other systems that changes its properties rather than the state parameters [23, 24].

The multidimensional polynom with approaching the mixed thermic models represents an improvement of the previous linear model. The expression for these models takes the following shape:

$$
\begin{aligned}
F=A_{0}+A_{1} t+ & A_{2} t^{2}+. .+D_{0} x t+. .+B_{1} x+B_{2} x^{2}+. .+ \\
& +C_{1} y+C_{2} y^{2}+E_{0} y t+. .
\end{aligned}
$$

where $F$ is the growth rate as a function, $x$ represents consistency value and $t$ is the current age. and $\mathrm{y}$ is the current magnitude of age. In this representation, the vertical axis represents SS magnitude, while the horizontal axis lists the polynomial range for time series, consistency and current age. The best performances are through the consistency polynomial expansion series and especially through the age polynomial expansion series (Figure 6).

The mixed terms introduced by D and E coefficients (2) eliminate the effects of Runge phenomenon for the interpolation of high order polynoms [23]. In this way, we can obtain a more precise model with fewer evaluation errors by using the models described above. The optimum polynomial model is model number 3 expressed through the relation (2) and represented in figure number 5 . In this 
way, we can obtain the best analytic model for evaluating the growth rate of white willow in comparison with the parameters measured by state.

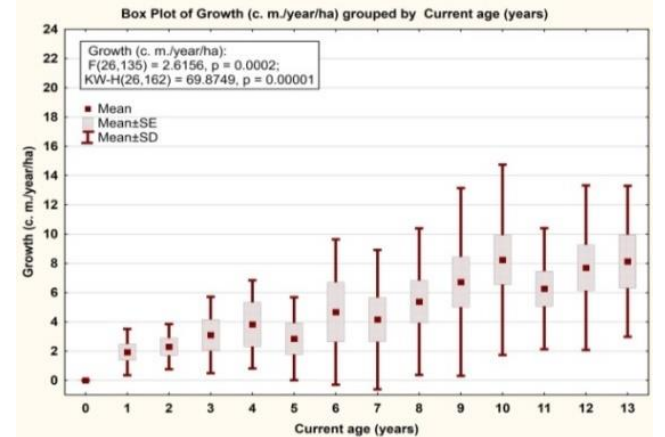

(a) Growth rate in comparison with current age

Fig. 6. The representation of the optimum multidimensional model with mixt configuration

\section{CONCLUSIONS}

The results of this research prove that certain indicators of stand structure that have been less studied (such as consistency and age) are important and should be taken into account in order to obtain a high efficiency in areas afforested with willow (Salix alba) from Hanu-Conachi Independenta Forest. The significant influence of these factors has led to a larger effect on growth rates and production volumes. The analysis was obtained from more methods and through comparison. The influence of the environment gradient proved to be of secondary importance, so these effects have been left out.

The problem of using and exploiting forests is a current worldwide issue. Optimizing costs and maximizing the production volume by influencing growth rates are important objectives, beside the economical ones. Furthermore, they lead to conserving forests. The results obtained in surfaces afforested with willow (Salix alba) can offer future management solutions that are of both national and international interest.

\section{REFERENCES}

[1] LAZAR, N., STANCIOIU, T., TUDORAN, G., SOFLETEA, N., CANDEA, BOGZA, S.B., PREDOIU, G., DONITA, N., INDREICA, A., MAZARE, G., Priority alpine, subalpine and forest habitats in Romania. Potential threats, Transilvania University Publishing House Brasov, 2007, pp. 37-50 [in Romanian].

[2] GAFTA, D., MOUNTFORD, J.O., Interpretation manual of Natura 2000 habitats in Romania, Risoprint Publishing House, Cluj-Napoca, 2008, p.7-95 [in Romanian].

[3] PETRESCU, M., CUZIC, V., PANAIT, V., CUZIC, M., Contributions to the knowledge of the natural heritage of some administrative territories from Tulcea County, 2012, p. 11-203 [in Romanian].

[4] DONITA, N., POPESCU, A., PAUCA-COMANESCU, M., MIHAILESCU, S., BIRIS, I.-A. Romanian Habitats, Tehnica Silvica Publishing House, Bucharest, 2005, p. 7-477 [in Romanian].

[5] FAO, 2008. Poplars, willows and people's well-beings: synthesis of country progress reports activities related to poplar and willow cultivation and utilization, 2004 through 2007, International Poplar Commission, 23 ${ }^{\text {rd }}$ session, Beijing, China, $27-30$ October 2008, https://www.fao.org/3/k3380e/k3380e00.htm.

[6] ILEK, A., SZOSTEK, M., KUCZA, J., STANEK-TARKOWSKA, J., WITEK, W., Ann. For. Res. 62, no. 12, 2019, p. 21.

[7] VIZITIU, D.E., DINCA, L., ENACHE, V., DONICI, A., POPA, L., COCIORVA, D., MURARIU, G., Proceedings Book of $21^{\text {st }}$ of International Symposium "The Environment and the Industry”, Bucharest, Romania, 20-21 September 2018, p. 232, https://doi.org/10.21698/simi.2018.fp28.

[8] RYTER, R.M., Biom. Bio. 36, 2012, p. 86. 
[9] GUOLONG, H., DELAANG, C.O, XIXI, L., LEI, G., Ann. For. Res., 62, no 1, 2019, p. 3.

[10] FARA, L., CINCU, C., HUBCA, G., FILAT, M., CHIRA, D., NUTESCU, C., FARA, S., ZAHARIA, C., DIACON, A., COMANECI, D., XVIIth CIGR World Congress, CSBE/SCGAB, 2010, p. 1-6.

[11] BOTU, I., BOTU, M., PREDA, S., ACHIM, G., LAZAR, A., ALECU, A., Biol. Environ., 4, no. 1,2013 , p. 35.

[12] SCRIBA, C., BORZ, S.A., TALAGAI, N., Forest Review, 3-4, 2014, p. 57 [in Romanian].

[13] HERNEA, C., CORNEANU, M., SARAC, I., TURCU, E., Biol. Environ., 7, no. 2, 2016, p. 115.

[14] CANTAR, I.C, CHISALITA, I., DINCA, L., Proceedings Book of $21^{\text {st }}$ of International Symposium "The Environment and the Industry", Bucharest, Romania, 20-21 September 2018, p. 32, https://doi.org/10.21698/simi.2018.fp03.

[15] DAVIDESCU, S., MURARIU, G., DINCA, L., VASILE, D., CRISAN, V., CRETU, R., GEORGESCU, L., DECA, S., Int. J. Conserv. Sci., 11, no.3, 2020, p. 807.

[16] HERNEA, C., NETOIU, C., CORNEANU, G., CRACIUN, C., CORNEANU, M., COJOCARU, L., ROVENA, LACATUSU, A., POPESCU, I., EGU General Assembly 2014, 27 April - 2 May, Vienna, Austria, 2014, id.9857.

[17] CONSTANDACHE, C., PETICILA, A., DINCA, L., VASIlE, D., AgroLife Sci. J., 5, no. 2, 2016, p. 50.

[18] CANTAR, I.C, CHISALITA, I., DINCA, L., International Scientific Conference on Earth and Geosciences-Vienna GREEN Scientific Sessions, Vienna, Austria, 3-6 December 2018, 18, (1.5), 2018, p. 757.

[19] CRISAN, V., DINCA, L., ENESCU, R., ONET, A., DECA, S., J. Environ. Prot. Ecol., 21, no. 2, 2020, p. 579.

[20] HIGHFIELD, E.S., KEMPER, K.J., Longwood Herbal Task Force, 1999: http://www.mcp.edu/herbal/default.htm.

[21] MURARIU, G., DINESCU, A., MURARIU, A. G., CONDURACHE-BOTA, Rom. J. Phys. 61, no. 3-4, 2017, p. 626.

[22] MURARIU, G., MURARIU, A. G., ITICESCU, C., STANCIU, S., DINCA, L., International Scientific Conference on Earth and Geosciences-Vienna Green Scientific Sessions, 18, (1.5), Vienna, Austria, 2018, p. 711.

[23] MURARIU, G., MUNTEANU, D., DOROSENCU, A., MURARIU, A., DINCA, L., TUDOR, M., DRAGU, M.D., VLAD, C., STANCIU, S., $22^{\text {nd }}$ International Conference on System Theory, Control and Computing (ICSTCC), Sinaia, Romania, 10-12 October 2018, p. 524.

[24] DINCA, L., MURARIU, G., ENESCU, C.M., ACHIM, F., GEORGESCU, L., MURARIU, A., TIMIS-GANSAC, V., HOLONEC, L., Not. Bot. Hort. Agrobot., 48, no.2, 2020, p.1070.

Citation: Murariu, G., Enescu, R., Vasile, D., Dinca, L., Mocanu, G.D., Munteanu, D., A study regarding the parameters that influence the growth rate of Salix alba, Rom. J. Ecol. Environ. Chem., 2021, 3, no.2, pp. 78-88.

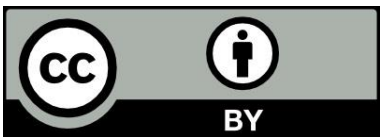

(C) 2021 by the authors. This article is an open access article distributed under the terms and conditions of the Creative Commons Attribution (CC BY) license (http://creativecommons.Org/licenses/by/4.0/). 